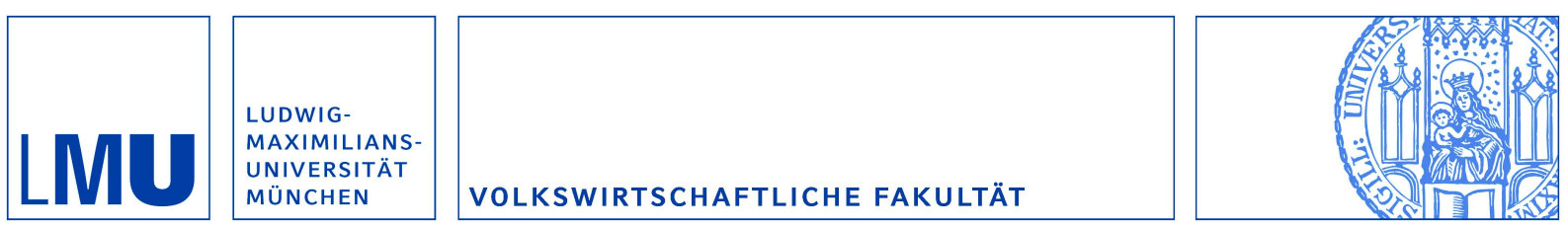

Marin, Dalia; Huang, Haizhou und Xu, Chenggang:

Financial Crisis, Economic Recovery and Banking Development in Former Soviet Union Economies

Munich Discussion Paper No. 2002-9

Department of Economics

University of Munich

Volkswirtschaftliche Fakultät

Ludwig-Maximilians-Universität München

Online at https://doi.org/10.5282/ubm/epub.27 


\title{
Financial Crisis, Economic Recovery and Banking Development in Former Soviet Union Economies*
}

\author{
Haizhou Huang, International Monetary Fund \\ Dalia Marin, University of Munich \\ Chenggang $\mathrm{Xu}$, London School of Economics
}

First Draft: September 2000

This Draft: September 2002

\footnotetext{
${ }^{*}$ We would like to thank Peter B. Clark, Gaston Gelos, Richard Layard, Anna Meyendorff, Enrico Perotti, Mark Schaffer, Jian-Guang Shen and participants at the CEPR/WDI International Transition Conference, Portoroz, International Conference on Financial Market Development in Emerging and Transition Economies, London Business School and Hong Kong, European Economic Association Meeting, Lausanne, CESifo Conference on Financial Crisis and Recovery, Venice, and participants at seminars at London School of Economics, ECARE, Free University Brussels, University of Mannheim, Munich, Bonn, Dartmouth College, and the Bank of Finland for their comments and suggestions; and Daniel Bauchet and Andzelika Lorentowicz for excellent research assistance. The paper was partly produced while Dalia Marin and Chenggang $\mathrm{Xu}$ visited the Research Department of the IMF. All remaining errors are our own, and the views are our own and do not necessarily represent those of the IMF or IMF policy. The insights of the paper were presented at a CEPR Policy lunch meeting in Brussels titled "Russia's Economic Recovery: A Windfall or more permanent Cure?"
} 


\begin{abstract}
This paper provides a unified theory to explain the onset of the financial crisis in 1998 and the striking economic recovery in Russia and the former Soviet Union afterwards. Before the crisis, the banking sector in these economies was stuck in a development trap in which the banking sector is separated from the real sector of the economy. The separation between the two sectors arises due to a lemons lending market and due to a large government budget. In a lemons credit market firms may find it cheaper to raise liquidity through non-bank finance (trade credits from other firms) rather than through bank finance. As a result non-bank finance may generate an externality on the lending rates of banks. In equilibrium most firms in the economy rely on non-bank finance and the financial sector focuses on trading government securities. The collapse of the treasury bills market in Russia in the financial crisis of 1998 reversed this process and thus acted as a trigger to pull the economy out of the trap. This has led to the strong economic recovery and provided initial conditions for banking development. Empirical evidence with firm level data from Ukraine in 1997 and with country level data for transition economies support the model's predictions.
\end{abstract}

JEL Classification: G3, G21, P34, O16, D82

Keywords: banking development, institutional trap, trade credit, nonbank finance, finance in emerging market economies 


\section{Introduction}

After the collapse of the Soviet Union, Russia and the other CIS countries took a bumpy road in their transition to a market economy. The real sector of the economy experienced a sharp contraction. Output collapsed to around 50 percent of its 1989 level in 1998 (see Table 1). During this period the real sector accumulated huge outstanding debt with money as a medium of exchange vanishing. As a result arrears and non-cash payments have become a dominant feature of the Russian economy. Total payables to the enterprise sector exploded from around 20 percent of GDP in 1994 to over 70 percent of GDP in 1998, while total receivables rose from 20 percent of GDP to about 45 percent of GDP over the same period. Barter and non-cash payments started to rise after macroeconomic stabilization in 1994 from 8 percent to over 50 percent of sales in 1998 (see Figure 1).

In contrast to the contraction of the real sector the Russian financial sector experienced an explosive growth in the number of commercial banks from fewer than 100 banks in 1988 to about 2400 banks in 1994 to about 1500 banks in 1998. Despite these large numbers of banks, the Russian banking sector is highly concentrated. In 1997, the top five banks accounted for 36 percent of total assets and the top 50 banks for 71 percent. About three quarters of all household deposits were maintained with Sberbank. Despite this boom in the financial sector, the Russian banking sector allocated very little credit to the real sector of the economy. Rubel loans (in nominal terms) to the economy declined by 31.7 percent from 180 billion ruble to 123 billion ruble between 1997 and 1998. In real terms the decline in bank credit to the economy was almost 60 percent. Commercial banks lending rates increased in nominal terms during this period (see Table 2). Due to high yields in the treasury bills market commercial banks concentrated their activity on this market. The share of federal government securities in commercial banks portfolios increased to almost three quarters of ruble deposit liabilities by the end of $1997 .^{1}$ A similar picture emerges for other countries of the former Soviet Union notably Ukraine (see Table 3). In fact, Russia and Ukraine are the transition countries who suffer most from an under-provision of bank intermediation, particularly in mobilising savings and in allocating credit to the private sector. Besides the relative low scale of banking, Russia and Ukraine experienced a continued decline in the scale of banking activity over time. The ratio of credit to the private sector

\footnotetext{
${ }^{1}$ see OECD Economic Surveys: Russian Federation 1997, Paris 1997-1998.
} 
to GDP declined from 12 percent in 1994 to 8 percent in 1997 in Russia and from 5 percent in 1994 to 2 percent in 1997 in Ukraine. This compares with an average for all the transition countries of 22 percent in 1994 to 23 percent in 1997.

Table 1

Level of Real GDP

in selected Transition Countries in 1998

\begin{tabular}{llll}
\hline & \multicolumn{2}{c}{$(1989=100)$} & \\
\hline CIS & 54 & Central Europe & 95 \\
Russia & 55 & Poland & 117 \\
Ukraine & 37 & Czech Republic & 93 \\
Azerbaijan & 44 & Hungary & 95 \\
Belarus & 78 & & \\
Kazakhstan & 61 & & \\
\hline
\end{tabular}

Source: International Monetary Fund 


\title{
Table 2 Bank Credit to the Real Sector in Russia
}

\author{
in billions of rubels
}

\begin{tabular}{cccccc}
\hline & total loans & $\begin{array}{c}\text { foreign } \\
\text { currency }\end{array}$ & ruble loans & interest rates ${ }^{1)}$ & inflation $^{2}$ \\
\hline 1996 & 247 & 117 & 130 & 146,8 & 47,7 \\
1997 & 310 & 130 & 180 & 32,0 & 14,7 \\
1998 & 422 & 298 & 123 & 41,8 & 27,7 \\
1999 & 597 & 304 & 293 & 39,7 & 85,7 \\
2000 & 956 & 368 & 588 & 24,4 & 20,8 \\
2001 & 1418 & 474 & 944 & 17,9 & 21,5 \\
\hline
\end{tabular}

Source: International Monetary Fund, Central Bank of Russia

${ }^{1)}$ commercial banks' 3 -months lending rates in percent

${ }^{2)}$ consumer price index in percent

After the August financial crisis in 1998, however, the recovery of output in Russia and Ukraine is much stronger than was expected. In fact, in 1999 Russia and Ukraine experienced positive growth for the first time since the fall of communism. The IMF has adjusted its forecast in its World Economic Outlook upwards several times. Output has grown in 1999 by 3.2 percent and in 2000 by 7.5 percent and is expected to grow by 4 percent in 2001 and 2002. Similarly, in Ukraine output recovered to 5 percent in 2000 and GDP is expected to grow by 6 and 9 percent in 2001 and 2002, respectively (see Figure 3). Total arrears and barter have started to decline in Russia. In particular, barter and non-cash payments dropped by 20 percent in 1999 and continue to decline in 2000 and 2001 (see Figure 1). ${ }^{2}$ Furthermore, commercial banks started to lend to the real sector. Ruble loans to the economy more than doubled in nominal terms between 1998 and 1999 from 123 bill rubles to 293 bill rubles. At the same time lending rates of commercial banks declined sharply in nominal as well as real terms (see Table 2 and Figure 1). Due to the collapse of the government treasury bills market,

\footnotetext{
${ }^{2}$ According to the interfax news agency the share of barter in sales dropped as well in Ukraine from 33 percent in 1999 to 17 percent in 2000 to 8 percent in 2001 .
} 
the large exposure of portfolios of commercial banks to this market made many banks insolvent. This has led to a further consolidation and concentration in the banking sector with 3 state banks (of which one is Sberbank) now accounting for about 80 percent of the assets. Moreover, Sberbank started to aggressively enter the lending market pushing some of the existing top banks out of this market. ${ }^{3}$ A similar picture emerges for Ukraine where bank credit to the private sector increased from 2 percent to 9 percent of GDP between 1997 and 1999 (see Table 3 and Figure 1).

\section{Table 3 Credit to the Private Sector in Transition Countries}

in percent of GDP

\begin{tabular}{lcccc}
\hline & 1994 & 1996 & 1997 & 1999 \\
\hline Azerbaijan & - & 1 & - & 3 \\
Belarus & 18 & 7 & 9 & 10 \\
Kazakhstan & 25 & 6 & 5 & 9 \\
Latvia & 16 & 7 & 11 & - \\
Lithuania & 18 & 11 & 10 & 10 \\
Russia & 12 & 7 & 8 & 12 \\
Ukraine & 5 & 1 & 2 & 9 \\
Czech Republic & 40 & 57 & 68 & 44 \\
Hungary & 26 & 22 & 24 & 21 \\
Poland & 12 & 16 & 18 & 19 \\
\hline
\end{tabular}

Source: International Monetary Fund, International Financial Statistics

\footnotetext{
${ }^{3}$ For the restructuring of the Russian banking sector after the crisis, see Interfax Center for Economic Analysis, Russia's Largest Banks in 1999, Moscow 1999.
} 
These developments are quite puzzling for several reasons. First, when macroeconomic stabilization was in place in Russia in 1994 arrears and barter started to explode. Thus, the non-cash economy in Russia does not appear to be a phenomenon of hyperinflation. Second, with the outbreak of the financial crisis in 1998 arrears and barter started to decline. This is not what one typically expects from a financial crisis. Third, with the outbreak of the financial crisis GDP in Russia and Ukraine recovers for the first time since the fall of communism. This stands in contrast to the experience of the Asian economies where the financial crisis led to a sharp output decline in many of these economies. ${ }^{4}$

The described developments in Russia and Ukraine raise the question whether there is a connection between these observations. More specifically, what explains the separation between the financial and the real sector? What is the relationship between the non-cash economy on the one hand and the development of the banking sector on the other? Has the stronger than expected recovery of the Russian and Ukrainian economies after the financial crisis in 1998 something to do with the fact that barter trade is declining and that the banking sector has started to provide finance to the real sector of the economy? What role played the financial crisis in this process?

We explore these questions based on a model which provides a link between the non-cash economy in Russia and the failure of the banking sector. We take the possibility for barter trade as given and focus in this paper on endogenizing the banking failure. ${ }^{5}$ We ask in this paper whether trade credits and barter trade can create a banking failure and thus can prevent the banking sector from developing as a financial institution. Given the difficulty for banks to distinguish good from bad debtors, banks charge high lending rates for loans to cover the risk. This, in turn, induces good quality firms to turn to trade credits and barter trade to solve their liquidity needs. The option for firms to raise liquidity through nonbank finance drives up banks lending rates. In equilibrium banks give loans to a

\footnotetext{
${ }^{4}$ Based on a sample of 195 crisis episodes across 91 developing countries, Gupta, Mishra, Sahay (2001) find in their study on ouput responses to financial crisis that around 60 percent of the crisis have been contractionary. Moreoever, Loayza and Ranciere (2001) find in the countries that experience a fall in output after crisis, that it takes on average 4 years for output to recover.

${ }^{5}$ In a recent paper Marin and Schnitzer (1999) argue that barter is a response to a banking failure. Barter is a trade credit between firms which is repaid in goods rather than cash. Marin and Schnitzer take the banking failure as given and argue that barter offers a deal-specific collateral which effectively lowers credit enforcement costs.
} 
small number of bad quality firms while the good quality firms turn to non-bank finance. The banking sector instead focuses on trading government securities. As a result the financial sector is separated from the real sector of the economy. The separating equilibrium features a trap in which non-bank finance hinders banking sector development. Based on data from a survey among firms in Ukraine in 1997, we test the predictions of the model and we indeed find that bank loans are allocated to firms with low quality.

Our theory offers an explanation for why a financial crisis may be beneficial and has helped the Russian economy to pull out of the trap of banking failure. Thus, our model helps to explain why the recovery in Russia after the August 1998 crisis was stronger than expected. We argue that the financial sector has been disconnected from the real sector because the Russian government has been over issuing bonds to finance the budget deficit when tax collection turned out to be difficult. The government offered exceptionally high yields on treasury bills which gave banks an incentive to finance the governments budget and to invest their assets in this market rather than to invest in the real sector. ${ }^{6}$ The crisis was triggered when the government defaulted on its debt and the securities market collapsed. Rather than leading to a total collapse of the banking sector (due to its large exposure to this market) the vanished market for government bonds induces banks to reallocate their assets to the real sector. Banks start to lower interest rates to attract firms to borrow. Lower lending rates, in turn, induces some better quality firms to start to borrow from banks rather than to engage in non-bank finance and barter. This, in turn, further lowers interest rates and induces more firms to switch from barter to borrowing from banks. This way, the financial crisis has provided an opportunity for the banking sector to develop. Our theory is able to account for the puzzling fact that after the crisis of 1998 the non-cash economy started to decline in Russia and Ukraine and the banking sector started to lend to the real sector and interest rates declined sharply. ${ }^{7}$ Based on data for 20 transition countries we test the prediction of the financial crisis as a trigger for

\footnotetext{
${ }^{6}$ According to Shleifer and Treisman (2000) this was the price Russia had to pay to achieve stabilization of inflation. Rather than printing money to finance the budget, the government issued treasury bills and maintained artificially high interest rates on these bills to co-opt the banks who havily invested in this market. Yields on the GKO market reached up to 60 percent (see Figure 1).

${ }^{7}$ During the crisis the ruble depreciated by more then fifty percent (see Figure 3) which may be an alternative explanation for why barter dropped after the August crisis in Russia. The devaluation of the ruble may have made Russian exports relatively inexpensive in international markets which may have earned Russian firms some cash in these markets. The exchange rate
} 
bank development. We show that the allocation of bank credit to the real sector of the economy is indeed hampered by the governments' overissuing of bonds and by the opportunity for firms to engage in barter trade.

Our theory suggests a link between the governments budget deficit and the non-cash economy which has been overlooked so far. In our model, the government's public debt creates the non-cash economy rather than the other way around. It is frequently argued that arrears and barter in Russia and Ukraine are driven by tax motives. By allowing to hide some of their profits lowering their tax base, non-bank finance is seen to contribute to the difficulty of raising taxes and thus causing the governments budget to explode. Our theory instead suggests that the governments' budget deficit is crowding out bank lending to the real sector by creating an environment in which banks invest in the treasury bills market with exceptionally high returns. As a result the real sector turns to non-bank finance to meet its liquidity needs. ${ }^{8}$

The paper is organized as follows. In section 2 we develop a model of the bankfirm relationship as a lemons market. In section 3 we characterize the equilibrium of a banking lemons market in which the financial and the real sector is separated. Section 4 describes how the financial crisis has helped the economies of the former Soviet Union to get out of the banking failure trap. In section 5 we test the predictions of the model with firm level data from Ukraine and with country level data for 20 transition economies. Section 6 concludes.

induced creation of liquidity may have helped firms to meet some of their liquidity needs with internal cash flow rather than through barter. However, Ukraine experienced a sharp drop in barter and arrears after 1998 as well with a mild depreciation of the exchange rate only which suggests that some other force is at work here. A common argument that the return to the cash economy in Russia is due to a reversal in capital flight after the August crisis does not seem to be supported by the data. Westin (2000) and Loungani and Mauro (2000) argue, that capital flight picked up again in Russia after the tightening of capital controls in the aftermath of the crisis.

${ }^{8}$ In the debate over the non-cash economy tax reasons figure prominently as an explanation. However, empiricial evidence for Russia and Ukraine suggests that tax motives have only minor importance, while the lack of liquidity and high borrowing costs for bank loans are the prime motivation for firms to engage in barter trade, see Commander and Mumssen (1999) for evidence in Russia, and Marin, Kaufmann, Gorochowskij (2000) for evidence in Ukraine. 


\section{Model}

We consider an economy with $M$ banks and $N$ firms, where $N>M$; and the government.

Firms: firm $i(i=1, \ldots, N)$ has a probability of being solvent, $\lambda_{i}$, which is only known by the firm. The quality level of firms can be ranked as $\lambda_{1}>\lambda_{2}>\ldots>\lambda_{N}$. But the ranking of firms is not known to any particular bank and firm. The average quality of all firms is $\bar{\lambda}_{N}=\frac{1}{N} \sum_{i=1}^{N} \lambda_{i}$, which is known to the firms and banks. The liquidity demand of firms can be met through borrowing from banks or through other means, such as borrowing from other firms in the form of trade credits in cash or in the form of trade credits in goods (barter trade) $)^{9}$. We will call these alternative forms of finance as non-bank-financing (NBF). To meet their liquidity needs profit maximizing firms choose the cheaper way between bank financing and NBF.

To simplify the analysis we assume that NBF cost $b=$ const. ${ }^{10}$ Cost savings when undertaking NBF may include avoiding hold-up as well as saving on taxes. It has been argued that NBF may help to solve the problem of disorganization in transition countries with weak contract enforcement. NBF can also be used to hide profits and thus give firms the opportunity to evade taxes. The NBF costs $b$ are a reduced form capturing these possibilities. ${ }^{11}$

Government: We suppose that the government's total revenue equals its tax revenue plus its borrowing. Given the possibility for tax evasion, the government is assumed not to be able to collect taxes effectively. For any given government revenue, $R$, the lower the tax revenue, $T$, the more the government issues bonds

\footnotetext{
${ }^{9}$ Overdue trade credits in cash (firm arrears) and trade credits in goods (barter) exploded in Russia and the former Soviet Union. Usually goods used in barter are not fixed assets and heterogeneous in quality. This means that these goods are typically not collaterizable assets for bank loans due to high cost of quality assessment or selling for banks. For barter as a collateralized trade credit, see Marin and Schnitzer (2002).

${ }^{10}$ This assumption can easily be relaxed without changing the qualitative results. For example, one could make $b$ to depend on firm characteristics like the firm's level of quality. However, as will become clear later this would reinforce the separation result we will derive in the next section without adding insight.

${ }^{11}$ For NBF as a solution to the hold-up problem and disorganization, see Marin and Schnitzer (1999); for empirical evidence on NBF and tax evasion in the former Soviet Union, see Commander and Mumssen (1999) and Marin, Kaufmann, Gorochowskij (2000).
} 
to finance its expenditures $B=R-T$. We assume that NBF firms evade taxes. ${ }^{12}$ When there are $n \mathrm{NBF}$ firms the tax revenue is reduced to $T=(N-n) t$, where $t$ is the tax paid by each firm. To borrow more, the yield of government bond, $s$, has to be higher. ${ }^{13}$ To capture this idea in a simple way, we assume that the yields of government bonds, $s$, is a positive linear function of the amount of borrowing. When there is no tax evasion the interest rate of government securities reaches its lower bound with $s=\phi r_{0}$, where $\phi$ is the investors' relative confidence in government securities. When the relative confidence in government securities is the same as that of investing in the private sector, then $\phi=1$; otherwise it is $\phi>1$. To make things simple, we treat $\phi$ as a reduced form and take $\phi$ and $t$ as exogenously given. ${ }^{14}$

To summarize, we have,

$$
\begin{aligned}
s(n) & =r \phi \frac{B(n)}{\bar{B}} \\
& =r \phi \frac{R-(N-n) t}{R-N t}
\end{aligned}
$$

where, $\bar{B}$ is planned government borrowing; and $B(n)$ is realized government borrowing.

Bank-firm relationship: We assume free entry in the banking sector. Facing competition, each bank makes its investment decision considering expected returns. If the expected return of investing in government securities is higher than that of lending to a firm, banks will invest in government securities rather than lend to firms.

We suppose that there is asymmetric information between banks and firms such that banks are not able to identify which firm is of good quality and which is of bad quality. Asymmetric information between banks and firms is a severe problem in transition economies. Most banks in transition economies are new and have very little experience with credit evaluation. Furthermore, the lack of

\footnotetext{
${ }^{12}$ Although in our model NBF is driven by financial considerations, NBF offers the possibility of evading taxes. This conforms well with the empirical evidence for Russia and the former Soviet Union, see Commander and Mumssen (1999) and Marin, Kaufmann, Gorochowskij (2000).

${ }^{13}$ The government can either issue government bond domestically with a high yield; or borrow from foreign investors by issuing dollar denominated bonds and paying higher interest rates.

${ }^{14}$ Alternatively, $\phi$ may also be interpreted as a risk premium on government securities.
} 
accounting standards and market valuation of firms' assets makes it difficult to evaluate firms' creditworthiness. The only information that banks are assumed to have is the average quality of the firms in the economy, $\bar{\lambda}_{N}$. Thus, banks' ex ante belief of the probability that a firm will be able to repay its loan is $\bar{\lambda}_{N}$. Therefore, banks' expected rate of return of lending to firms is $r_{N} \bar{\lambda}_{N}$, where $r_{N}$ is the rate of repayment of a solvent firm when there are in total $N$ firms borrowing. Comparing the expected rate of return of lending to a firm and investing in government securities, the arbitrage condition for a bank is

$$
\left(1+r_{N}\right) \bar{\lambda}_{N}=1+s
$$

Or the rate that a bank will charge to a firm will be

$$
r_{N}=(1+s) / \bar{\lambda}_{N}-1 \text {. }
$$

Facing this rate, $r_{N}$, a firm $i$ with a probability of success of $\lambda_{i}$, will face an expected marginal cost of borrowing from the bank of

$$
\lambda_{i}\left(1+r_{N}\right)=(1+s) \frac{\lambda_{i}}{\bar{\lambda}} .
$$

If raising liquidity through $\mathrm{NBF}$ is less costly than borrowing from banks, firm $i$ will borrow from other firms. The condition for this to happen for firm $i$ is then

$$
b \leq \frac{(1+s) \lambda_{i}}{\bar{\lambda}_{N}} .
$$

Thus, we have,

Lemma 2.1. Firm $i$ will use NBF if and only if:

$$
\frac{\bar{\lambda}_{N}}{\lambda_{i}} \leq \frac{1+s}{b}
$$

Notice that $\frac{1+s}{b}$ is the ratio between the yields of government bonds, which also determines the banks lending rates and thus the cost of raising $\$ 1$ liquidity through a bank loan, and the cost of raising $\$ 1$ liquidity through NBF. Obviously, comparative statics of the above condition implies that a firm is more likely to use NBF to solve its liquidity constraint, when the marginal cost of NBF $b$, is low, or the interest rate charged by banks, $s$, is high. Moreover, the higher is the quality of a firm, $\lambda_{i}$, the more likely it engages in NBF. This result comes 
with no surprise. With information asymmetry between banks and firms, banks charge an interest rate according to the market average quality. As a result the high quality borrowers subsidize the low quality borrowers in the pool of different quality borrowers. Turning to NBF helps this high quality firms to escape to subsidize the low quality firms.

\section{Separation of the Financial and the Real Sector}

In the previous section, we have shown that in a lemons lending market good quality firms face higher borrowing costs than bad quality firms. As a result good quality firms are more likely to look for other ways to solve their liquidity problems (e.g. through $\mathrm{NBF}$ ) than to borrow from banks. However, when better quality firms look for other options than borrowing this will lower the average quality of the pool of borrowing firms that come to the banks. This generates an externality on the lending rates of banks. The cost of borrowing goes up which, in turn, leads more good quality firms to turn away from banks. This logic repeats until in equilibrium only the bad quality firms borrow from banks and the good quality firms raise liquidity through $\mathrm{NBF}$. As a result the financial sector is separated from the real sector of the economy. In the following we show this separating equilibrium formally.

First, we illustrate conditions for a separating equilibrium between the financial and real sector when $s$ is exogenously given. We derive a separating equilibrium with $s$ being endogenized further down below. To make things simple, we assume that $\lambda_{i}=\lambda_{i-1}-\mu$ for all $i=1,2, \ldots, N$, and $\lambda_{N}=\mu$. Under this assumption, the average quality of all firms is

$$
\bar{\lambda}_{N}=\frac{1}{N} \sum_{i=1}^{N} \lambda_{i}=\frac{(1+N) \mu}{2} .
$$

The firms' quality can be ranked as $\lambda_{1}>\lambda_{2}>\ldots \lambda_{n-1}>\lambda_{n}>\ldots>\lambda_{N}$. We assume that the ranking is not known to any agent in the economy. Let us suppose that $\lambda_{n}$ satisfies the following condition,

$$
\lambda_{n-1}>\frac{b \bar{\lambda}_{N}}{1+s}>\lambda_{n}
$$


According to Lemma 1, this condition implies that firms with subscript $i \leq n-1$ will not borrow from banks because their cost of borrowing is too high. All other firms with $i \geq n$ will find it cheaper to borrow from banks. Thus, at the starting point the $n-1$ high quality firms do not borrow from banks.

In the following lemma, we show for exogenously given $s$ that when the bank lending market is a lemons market, in equilibrium the higher the ratio $\frac{1+s}{b}$, the fewer firms will borrow from banks.

Proposition 3.1. Lemma 3.2. There are three possible equilibria in a lemons bank lending market:

Lemma 3.3. 1. if $1 \leq \frac{1+s}{b}$, the equilibrium is $n^{*}=N$ and no firm borrows from banks; however,

2. if $\frac{N+2}{2(N+1)} \geq \frac{1+s}{b}$, the equilibrium is $n^{*}=0$ and all firms borrow from banks; finally,

3. if $\frac{N+2}{2(N+1)}<\frac{1+s}{b}<1$, there exists an equilibrium $n^{*} \in(0, N)$ such that all firms with subscript $i \leq n^{*}$ do not borrow, while all the remaining $N-n^{*}$ firms borrow from banks.

Proof. Given the quality rank of firms, $\lambda_{1}>\lambda_{2}>\ldots \lambda_{n-1}>\lambda_{n}>\ldots>\lambda_{N}$, without loss of generality, let us start with firm $n$. This firm will borrow for given $\bar{\lambda}_{N}$ and $s$; but all $n-1$ better quality firms do not borrow in the lending market. However, the $n-1$ firms' withdrawal from the lending market lowers the average quality of the remaining $N-n+1$ firms

$$
\begin{aligned}
\bar{\lambda}_{N-n+1} & =\frac{1}{N-n+1} \sum_{i=1}^{N-n+1} \lambda_{i} \\
& =\frac{(1+N-n+1) \mu}{2} \\
& <\frac{(1+N) \mu}{2} \\
& =\bar{\lambda}_{N} .
\end{aligned}
$$


The lower average quality of the pool of borrowing firms may make firm $n$ decide not to borrow. Given the quality of firm $n$

$$
\lambda_{n}=(N-n+1) \mu
$$

applying Lemma 1, the general condition for firm $n$ not to borrow is $\bar{\lambda}_{N-n+1} / \lambda_{n} \leq$ $\frac{1+s}{b}$, or

$$
\frac{(1+N-n+1) \mu}{2(N-n+1) \mu} \leq \frac{1+s}{b} .
$$

Rewrite the above NBF condition as

$$
\psi(n)=\frac{b(N-n+2)}{2(N-n+1)}-1 \leq s .
$$

Where, the banking lemons market equation $\psi(n)$ is defined as

$$
\psi(n) \equiv b \frac{\bar{\lambda}_{N-n+1}}{\lambda_{n}}-1
$$

It is easy to see that $\psi(n)$ is a convex increasing function of $n$ with $\psi(0)=$ $\frac{b(N+2)}{2(N+1)}-1$ and $\psi(N)=b-1$. Thus, if $\psi(N)=b-1 \leq s$, the equilibrium is $n^{*}=N$, i.e. no firm borrows.

Furthermore, if $\psi(0)=\frac{b(N+2)}{2(N+1)}-1 \geq s$, by Lemma 1, all firms will borrow and the equilibrium is $n^{*}=0$.

Finally, if $\psi(0)=\frac{b(N+2)}{2(N+1)}-1<s$ and $\psi(N)=b-1>s$, there exists $n^{*} \in(0, N)$ that $\psi\left(n^{*}\right)=s$.

Concerning the stability of the equilibrium, it is easy to see that for any firm $i$, where $i \leq n^{*}, \psi(i)<s(i)$. Thus, firm $i$ will not borrow from banks which will push more firms to choose not to borrow until $i=n^{*}$. Moreover, for any firm $j$, where $j>n^{*}, \psi(j)>s(j)$. Thus, firm $j$ will borrow which pushes more firms to choose to borrow until $j=n^{*}$. Thus, $n^{*}$ is a stable equilibrium.

So far we have assumed that the yields of government bonds $s$ is exogenously given. However, $s$ will depend also on the number of NBF firms in the economy. In the following, we endogenize the yields of government bonds $s$ to make its value 
depends on the number of NBF firms in the economy. Substituting $s(n)$ into the condition in Lemma 2, the no-borrow condition becomes

$$
s(n) \geq \psi(n)
$$

with

$$
s(n)=\phi r_{0}\left(1+\frac{t}{R-N t} n\right)
$$

as the government securities yields equation; and

$$
\psi(n)=\frac{b(N-n+2)}{2(N-n+1)}-1
$$

as the banking lemons market equation. The following proposition gives conditions for a separating equilibrium in which the good quality firms do not borrow from banks. ${ }^{15}$

Proposition 3.4. If $(b-1)\left(1-\frac{t N}{R}\right)>\phi r_{o}>\frac{b(N+2)}{2(N+1)}-1$ a unique interior equilibrium $n^{*} \in(0, N), s^{*} \in\left(\phi r_{o}, \frac{\phi r_{0} R}{R-N t}\right)$ exists such that $n^{*}$ better quality firms do not borrow and the remaining $N-n^{*}$ low quality firms borrow from banks. Moreover, the equilibrium value of $n^{*}, s^{*}$ increase with $t, \phi r_{o}$ and decrease with $R$.

Proof. Notice that $s(n)$ is a linear upward sloping function with $s(0)=\phi r_{o}$, and $s(N)=\frac{\phi r_{0} R}{R-N t}$. Moreover, $\psi(n)$ is a convex upward sloping function with $\psi(0)=\frac{b(N+2)}{2(N+1)}-1$, and $\psi(N)=b-1$.

If $s(0)>\psi(0)$ and $s(N)<\psi(N)$ a unique interior equilibrium exists that $n^{*} \in(0, N)$ and $s^{*} \in(s(0), s(N))$. Rewriting $s(N)=\frac{\phi r_{0} R}{R-N t}<\psi(N)=b-1$ as $(b-1)\left(1-\frac{t N}{R}\right)>\phi r_{o}=s(0)$ and combining with $s(0)>\psi(0)$ we have the conditions stated in the proposition.

Intuitively, when the number of NBF firms increases, the government's tax revenue $T$ declines, which in turn pushes up the yields of government bonds, $s$.

\footnotetext{
${ }^{15}$ The result shows only the case that is most relevant to our evidence. A full characterization of the equilibria of the model is available upon request.
} 
This, in turn, may lead more firms not to borrow from banks. The switching from borrowing to NBF will generate a negative externality on other borrowing firms who may stop borrowing as well. As a consequence $s$ is pushed further up which will again induce more firms not to borrow. This cycle repeats until $s$ is too high to attract more borrowers; or the borrowing firms are of too poor a quality to switch to NBF.

Concerning the stability of the equilibrium $\left(n^{*}, s^{*}\right)$, it is easy to see that for any firm $i$, where $i \leq n^{*}, \psi(i)<s(i)$. Thus, firm $i$ will not borrow from banks pushing up $s$ and leading more firms to choose not to borrow. This makes $\psi(i)$ increase faster than $s(i)$ until $i=n^{*}$. Moreover, for any firm $j$, where $j>n^{*}$, $\psi(j)>s(j)$. Thus, firm $j$ will borrow pushing down $s$ and leading more firms to choose to borrow. This makes $\psi(i)$ decrease faster than $s(i)$ until $j=n^{*}$. Thus, $\left(n^{*}, s^{*}\right)$ is a stable equilibrium. Given that $s(n)$ increases (decreases) with $t, \phi r_{o}$ $(R)$, the comparative static results follow.

The above result illustrates a banking development trap. Banks invest in financial assets, such as government bonds. Firms are squeezed out from the financial sector and only bad quality firms rely on bank loans. Firms, in particular good ones, solve their liquidity problems through NBF. The economy is stuck in a separation between the real sector and the banking sector - a banking development trap.

Our separation result between the real and the banking sector is substantially different from a conventional 'government crowding out' story. To illustrate the importance of the lemons lending bank market we calibrate the model with data from Russia in 1997 before the August financial crisis has hit the eocnomy. The following example demonstrates how the degree of information asymmetry between banks and firms worsens the separation between the two sectors.

For the simulation we choose the following parameters. To approximate the benchmark banks lending rates $r$ in our model we use the commercial banks lending rates of the Czech republic as a transition country with an established banking sector. The lending rates were $13.2 \%$ in 1997 and $8.7 \%$ in 1999 . Thus we select $10 \%$ for $r$. Total government expenditeure in percent of GDP in Russia is $18.4 \%$ in 1997 . Thus we choose $18 \%$ for $R$. Since planned tax revenue $T$ is not observable we assume a value of 10 for $T$. 
Example 3.5. The Role of Information Asymmetry: We consider two economies which differ in the degree of information asymmetry between banks and firms but share all other parameter values with $r=0.10, \phi=1.5, b=2.1, R=18$, $T=10$. We capture the degree of information asymmetry in the two countries by the number of firms in the real sector of the economy $N$. The idea is that the larger the number of firms in the economy the more heterogenous their quality increasing the information problem that banks face.

Case 1: Moderate degree of information asymmetry: $N=10$. Graph 1 gives the resulting banking lemons market curve $\psi(n)$ and the government securities yields line $s(n)$. The intersection of the two curves gives the equilibrium at point $\mathrm{T}$ at which 61 percent of the firms do not borrow from banks and the government security rate $s$ settles at 26 percent. In Russia in 1997 more than 50 percent of firms' sales were financed by other firms in the form of barter transactions and the treasury bills market rate reached 28 percent (see Figures 1 to 3 ). Thus, for reasonable parameter values the model is quite consistent with the data for Russia in 1997.

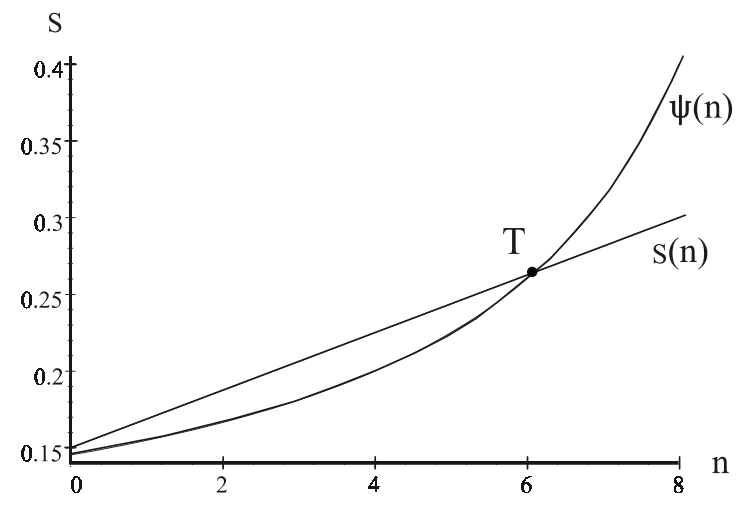

Graph 1: Moderate information asymmetry

Case 2: High degree of information asymmetry: $N=160$. Graph 2 gives the corresponding $\psi(n)$ curve and $s(n)$ line. At the new equilibrium at point $\mathrm{T} 98$ percent of the firms are involved in NBF and the treasury bill rate reaches 33.4 percent. 


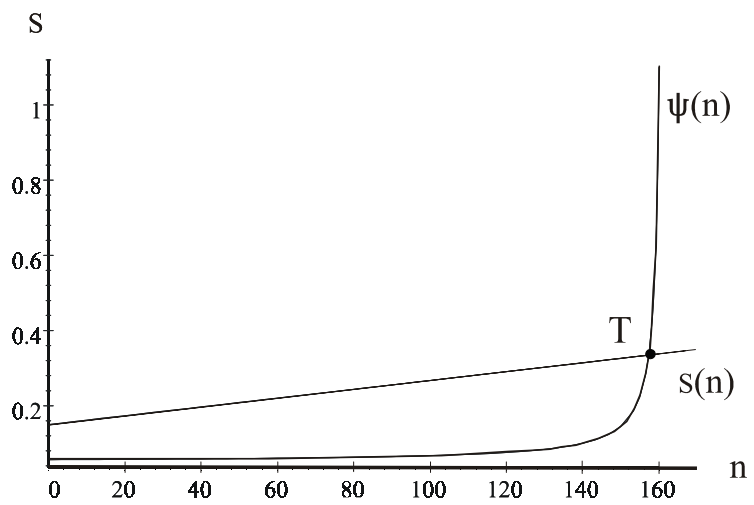

Graph 2: High information asymmetry

The example illustrates that an economy with a higher degree of information asymmetry suffers from a stronger separation between the real sector and the banking sector. A conventional crowding out story would not depend on the degree of information asymmetry between banks and firms as is the case here.

\section{Financial Crisis and Banking Development}

In the previous section we have derived an equilibrium in which the financial sector is separated from the real sector and the yields of government securities $s$ are high. In this section we analyze how an exogenous shock in the agents confidence in the government which is triggered by the government's default and the firesale of government securities will affect an economy with a separated financial and real sector.

A negative confidence shock leads to a major drop in $\phi$ and with it in the yields of government securities $s .{ }^{16}$ As a result, the banks which are heavily invested in government securities will suffer major losses. The direct effect of such a financial crisis on the real sector is, however, limited when the two sectors are separated.

\footnotetext{
${ }^{16}$ To make the model simple, we choose to treat the financial crisis as an exogenous event. Our analysis focuses on the consequences of a financial crisis.
} 
Corollary 4.1. With the separation between the banking sector and the real sector, the plunge of $\phi$ has no direct impact on the number of good quality firms $n^{*}$ which do not borrow from banks, although banks may make losses.

Typically, a financial crisis leads to a sharp fall in output in economies expieriencing such crisis. Furthermore, output recovers only slowly after a crisis hits. ${ }^{17}$ In an economy in which the financial and the real sector are separated, a financial crisis may, in fact, be beneficial for the recovery of output. When $\phi$ and $s$ plunge, banks' options outside of the real sector disappear. This induces banks to lower lending rates to attract more firms. As a result, some better quality firms will switch to borrow from banks which improves the average quality of the borrowing pool. The improved quality of the borrowing pool will further lower bank lending rates inducing more firms to borrow. Moreover, when more firms borrow, tax revenue $T$ goes up. This reduces government borrowing, which leads to a further drop in $s$. This logic leads to a new equilibrium in which better quality firms borrow from banks; loan interest rates go down; and banks invest less in government securities. The 'separation' syndrome may disappear if the shock is sufficiently strong.

Starting from an economy where $n^{*}$ good quality firms do not borrow from banks, we show now that the banking sector connects with the real sector when $\phi$ drops.

Proposition 4.2. If the banking sector is separated from the real sector in an economy, a financial crisis caused by a plunge of $\phi$ may lead to an integration of the two sectors. In the new equilibrium, the 'separation' syndrome may diminish or even disappear.

Proof. We are going to show two possible cases when $\phi$ is reduced to $\phi^{\prime}$. Notice that $\psi(n)$ is independent from $\phi$; and further notice that $s(n)$ is a linear increasing function of $\phi$.

\footnotetext{
${ }^{17}$ see footnote 5.
} 
1. If $\phi^{\prime}$ is reduced moderately a unique stable interior equilibrium $n^{c} \in\left(0, n^{*}\right)$ exists such that $n^{c}$ firms barter trade and the number of bartering firms is reduced. This is because with a lower $\phi^{\prime}$ that

$$
\phi^{\prime} r_{o}>\frac{b(N+2)}{2(N+1)}-1 \text {. }
$$

Applying Proposition 1 we have the result.

2. If $\phi^{\prime}$ is reduced substantially then in equilibrium $n^{c}=0$, i.e. all firms borrow. This is because with a drastic reduction of $\phi$ to $\phi^{\prime}$ that

$$
\phi^{\prime} r_{o} \frac{R}{R-t N}<\frac{b(N+2)}{2(N+1)}-1
$$

which implies $s(N)<\psi(0)$, then in equilibrium $n^{c}=0$.

Intuitively, when the exogenous shock is sufficiently big, a financial crisis may destroy banks opportunities in trading government bonds. By knocking out this 'outside option' banks are lured to lend to the real sector which drives the economy out of the banking failure trap. Moreover, it provides conditions for banking development as banks invest more in the real sector rather than in government bonds.

Our results describe well what has happened in Russia. The financial crisis in Russia was triggered by the default of the government in the bond market. Investors lost their confidence in government securities leading to a collapse of the treasury bill market. Banks made big losses from trading government bonds inducing them to look for new opportunities to lend and to make money. Indeed, comparing bank lending to the private sector in 1997, the year before the financial crisis, with that in 2000, reveals an increase in bank lending in Russia and in Ukraine from 8 percent and 2 percent of GDP, respectively, to 12 percent and 9 percent of GDP, respectively, while barter trade delined by about 30 percent.

It is important to point out that although the financial crisis may destroy the bad equilibrium of a banking failure trap and may thus provide an opportunity for banking development, this is by no means guaranteed. This is because information asymmetry is the key factor which causes the separation between the real sector and the banking sector. As long as information asymmetry between banks 
and firms is severe, a financial crisis may not be able to act as a trigger to pull the economy out of a banking development trap. Indeed, the following example illustrates that when the degree of information asymmetry is large enough, the lemons market problem is so serious that a financial shock is not enough to pull the economy out of a banking development trap.

Example 4.3. The Effectiveness of Financial Crisis for Banking Development: The Role of Information Asymmetry. We look at two economies with the same parameter values given by $r=0.10, b=2.1, T=10, R=18$. The initial value of confidence into government securities is the same, $\phi=1.8$. The only difference between the two economies is assumed to be the degree of information asymmetry.

Case 3: Moderate degree of information asymmetry: $N=10$. Graph 3 gives the $\psi(n)$ curve and the lines $s(n)$ and $s^{\prime}(n)$ before and after, respectively the financial crisis hits the economy. Before the shock (which is captured by a drop in $\phi$ from 1.8 to 1.2 ) the equilibrium settles at point $\mathrm{T}$ at which 74 percent of the firms are involved in NBF with a government security rate of 34.8 percent. After the shock (a drop in $\phi$ to 1.2), in the new equilibrium no firm engages in NBF and the treasury bill rate is 12 percent.

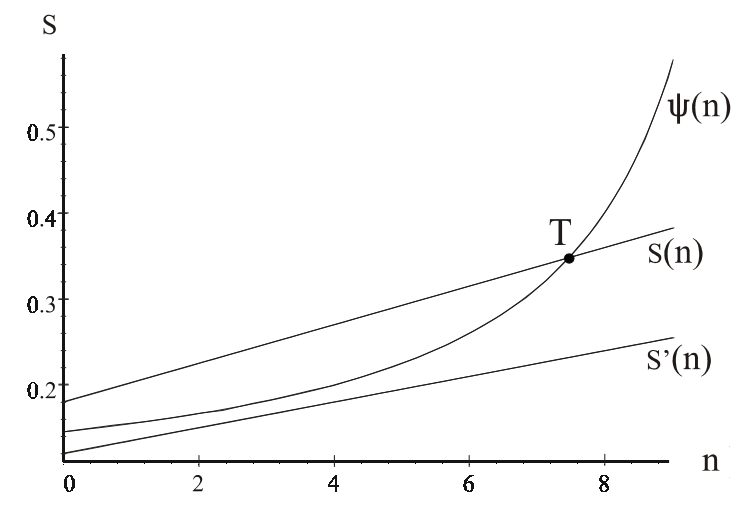

Graph 3: Moderate information asymmetry

Case 4: High degree of information asymmetry: $N=160$. Graph 4 gives the $\psi(n)$ curve with three lines before the financial shock $s(n)$, after a moderate financial shock $s^{\prime}(n)$, and finally after a drastic financial shock $s^{\prime \prime}(n)$. Before the 
shock, the economy settles at an equilibrium $\mathrm{T}$ at which 98.8 percent of the firms engage in NBF and the government security rate is 40 percent. With the same moderate shock as in Graph 3 (captured by a drop in $\phi$ from 1.8 to 1.2) the new equilibrium at T' still gives 97.6 percent of firms involved in NBF and a treasury bill rate of 12.1 percent. Only with a drastic drop of $\phi$ from 1.8 to 0.3 is the NBF economy removed and no firm barter trades with a government security rate of 3 percent.

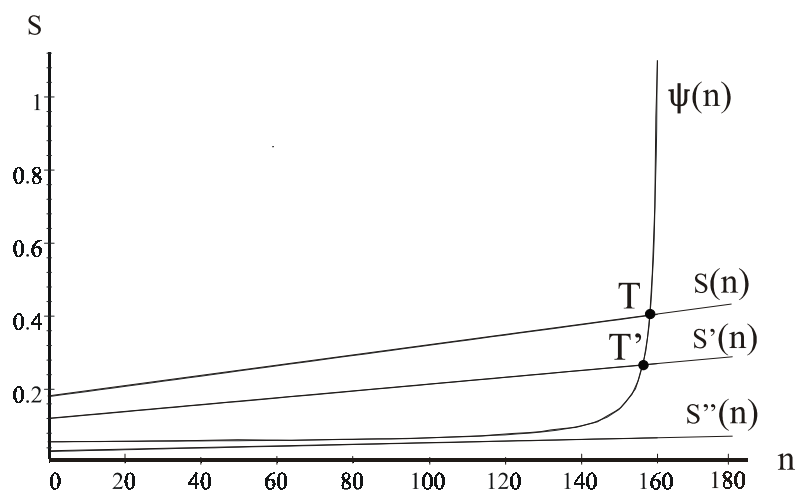

Graph 4: High information asymmetry

The example illustrates that a small financial shock is sufficient to bring an economy out from the separation between the real sector and the banking sector if the degree of information asymmetry is low. However, a large shock is required to do the same for an economy with a high degree of information asymmetry. The example demonstrates how the financial shock interacts with the degree of information asymmetry and thus highlights the relative importance of each for bank development.

\section{Empirical Evidence}

\subsection{Firm Level Evidence}

In this section we examine the predictions from our model with data of about 100 firms who engaged in barter trade in Ukraine in 1997. We interviewed 55 firms to obtain information on 165 barter deals. Each firm provided us with 3 barter 
deals. Each barter deal involved 2 firms, a seller and a buyer. Many of the firms were well informed about the financial and economic conditions of the firms they traded with because they served as financiers. This is how we obtained firm level information for about 100 firms (depending on the variable). Table 4 and Table 6 take a first look at the data and give descriptive statistics of the variables used in the empirical analysis. ${ }^{18}$

Our model predicts that low quality firms will predominantly finance their production with bank loans. We examine the relationship between bank lending and the characteristics of firms in Table 5. In the table we run the regressions for all firms in the sample (first five columns) and then for firms with positive bank debt only. We use the firms' bank debt in percent of sales DEBT as the dependent variable. 62 percent of the firms have positive bank debt with an average ratio of bank debt to firms sales of 6.3 percent (see Table 6). As a measure for the firms' quality $\lambda_{i}$ we use the variable QUALITY, which is defined by the firms' productivity. Another aspect of the firms' quality is captured by firms' arrears in percent of sales, and we denote this measurement by ARREARS. The more indebted the firm is vis-a-vis other firms the less likely it is that the firm will be able to repay its bank loans and thus the larger the banks' credit risk. Thus, our theory predicts a positive sign on the ARREARS variable. Turning to the results it appears that QUALITY is significant and negative and ARREARS is significant and positive in all specifications. ARREARS and QUALITY, both measuring the firms'quality appear to be correlated (when ARREARS is included, QUALITY becomes insignificant). Therefore, we excluded ARREARS in the remaining specifications shown in columns 4 and 5 .

Next, we include BARTCOST and TOT as variables capturing the cost of barter trade $b$. BARTCOST is an index which takes the value of zero if the firms output is produced with only one input and approaches one when the firm uses several inputs from other sectors. We use BARTCOST here as a measure of the cost of raising liquidity via barter. When a firm trades in many inputs it will have more leverage in barter trading between varieties of goods and thus will have lower bartering cost. We expect a negative coefficient on BARTCOST. ${ }^{19}$ Turning to the

\footnotetext{
${ }^{18}$ For a more detailed description of the data sample see Marin, Kaufmann, Gorochowksij (2000).

${ }^{19}$ Blanchard and Kremer (1997) use the same variable as a measure for the hold-up problems of firms. The larger the number of inputs used for production the more complex the production and the more bargaining problems arise. In their theory of barter Marin and Schnitzer (1999)
} 
results BARTCOST is negative and significant suggesting that firms with higher barter costs borrow more from banks.

Finally, we include the variable TOT into the regression which captures the terms of trade effect of barter. We will use it here as a measure for the credit costs of barter. TOT measures in percent the extend to which barter shifts the terms of trade in favor of the firm extending a trade credit within barter. The larger the shift in the terms of trade the more costly it is to raise liquidity via barter trade. For given costs for bank loans an increase in the credit costs of barter induces firms to switch to bank loans to solve their liquidity needs and thus we expect a positive sign on the TOT variable. TOT turns out to be positive and highly significant at conventional levels.

Lastly, we introduce the variables STATED and EMPLOY to control for ownership and firm size. One possible reason why the bad quality firms receive more bank loans than other firms is that the bad firms may be state owned and/or large. State owned firms or large firms may have better creditworthiness because of the expectation of a state bail out. It turns out, however, that neither STATED nor EMPLOY are significant at conventional levels in the all firms regressions. In the regressions for firms with positive bank debt (last five columns) STATED is not significant and firm size appears to hinder the firm to get loans (the relationship is significant and negative). The variable GROWTH is the firms' output growth relative to GDP growth in Ukraine between 1994 and 1996 and is supposed to control for the fact that firms with access to bank loans can grow faster. The relationship is strong and highly significant.

suggest lower bartering costs for firms with more complex production. They argue that barter trade helps firms to deal with the hold-up problem. 
Table 4

\begin{tabular}{|c|c|c|c|c|c|c|}
\hline & & & \multicolumn{4}{|c|}{ bank debt in percent of sales } \\
\hline & & & $\underline{0-105}$ & $\underline{0}$ & $\underline{0-10}$ & $\underline{10-105}$ \\
\hline & & & $100 \%$ & $38 \%$ & $52 \%$ & $10 \%$ \\
\hline \multirow[b]{2}{*}{ QUALITY } & mean & & 19490 & 23269 & 18168 & 12000 \\
\hline & $\begin{array}{l}\text { Anova: F-test } \\
\text { sign. level }\end{array}$ & $\begin{array}{c}1,30 \\
(0,276) \\
\end{array}$ & & & & \\
\hline \multirow[b]{2}{*}{ BARTCOST } & mean & & 0,802 & 0,823 & 0,800 & 0,752 \\
\hline & $\begin{array}{l}\text { Anova:F-test } \\
\text { sign. level }\end{array}$ & $\begin{array}{c}2,13 \\
(0,123) \\
\end{array}$ & & & & \\
\hline \multirow[b]{2}{*}{ GROWTH } & mean & & 0,03 & $-1,23$ & 0,17 & 4,08 \\
\hline & $\begin{array}{l}\text { Anova:F-test } \\
\text { sign. level }\end{array}$ & $\begin{array}{r}10,53 \\
(0,000) \\
\end{array}$ & & & & \\
\hline \multirow[b]{2}{*}{ TOT } & mean & & 4,55 & 2,79 & 4,10 & 13,53 \\
\hline & $\begin{array}{l}\text { Anova:F-test } \\
\text { sign. level }\end{array}$ & $\begin{array}{c}2,02 \\
(0,136) \\
\end{array}$ & & & & \\
\hline \multirow[b]{2}{*}{ ARREARS } & mean & & 30,1 & 16,9 & 17,2 & 137,0 \\
\hline & $\begin{array}{l}\text { Anova:F-test } \\
\text { sign. level }\end{array}$ & $\begin{array}{c}13,81 \\
(0,000)\end{array}$ & & & & \\
\hline \multirow[b]{2}{*}{ EMPLOY } & mean & & 4679,9 & 1121,3 & 7222,5 & 4981,4 \\
\hline & $\begin{array}{l}\text { Anova:F-test } \\
\text { sign. level }\end{array}$ & $\begin{array}{c}1,85 \\
(0,162)\end{array}$ & & & & \\
\hline
\end{tabular}

Source: Data Sample of 165 Barter Deals in Ukraine in 1997 
Determinants of Bank Lending to Firms

\begin{tabular}{|c|c|c|c|c|c|c|c|c|c|c|c|}
\hline & \multicolumn{5}{|c|}{ all firms } & \multicolumn{6}{|c|}{ firms with bank debt } \\
\hline & (1) & (2) & (3) & (4) & (5) & (1) & (2) & (3) & (4) & (5) & (6) \\
\hline $\ln$ (QUALITY) & $\begin{array}{l}-0,257 \\
(0,124)\end{array}$ & $\begin{array}{l}-0,318 \\
(0,052)\end{array}$ & $\begin{array}{c}-0,238 \\
(0,156)\end{array}$ & $\begin{array}{r}-0,358 \\
(0,034)\end{array}$ & $\begin{array}{l}-0,341 \\
(0,052)\end{array}$ & $\begin{array}{l}-0,363 \\
(0,011)\end{array}$ & $\begin{array}{r}-0,493 \\
(0,001)\end{array}$ & $\begin{array}{c}-0,549 \\
(0,000)\end{array}$ & $\begin{array}{l}-0,430 \\
(0,002)\end{array}$ & $\begin{array}{c}-0,554 \\
(0,000)\end{array}$ & $\begin{array}{c}-0,659 \\
(0,000)\end{array}$ \\
\hline $\ln (\mathrm{BARTCOST})$ & $\begin{array}{r}-1,804 \\
(0,065)\end{array}$ & $\begin{array}{l}-1,661 \\
(0,080)\end{array}$ & $\begin{array}{c}-1,283 \\
(0,176)\end{array}$ & $\begin{array}{r}-1,729 \\
(0,069)\end{array}$ & $\begin{array}{c}-1,730 \\
(0,070)\end{array}$ & $\begin{array}{r}-1,682 \\
(0,011)\end{array}$ & $\begin{array}{r}-1,283 \\
(0,049)\end{array}$ & $\begin{array}{r}-1,074 \\
(0,074)\end{array}$ & $\begin{array}{l}-0,854 \\
(0,141)\end{array}$ & $\begin{array}{r}-1,086 \\
(0,073)\end{array}$ & $\begin{array}{r}-1,146 \\
(0,055)\end{array}$ \\
\hline GROWTH & $\begin{array}{l}0,137 \\
(0,001)\end{array}$ & $\begin{array}{l}0,151 \\
(0,000)\end{array}$ & $\begin{array}{l}0,144 \\
(0,000)\end{array}$ & $\begin{array}{l}0,152 \\
(0,000)\end{array}$ & $\begin{array}{l}0,151 \\
(0,000)\end{array}$ & & $\begin{array}{l}0,075 \\
(0,005)\end{array}$ & $\begin{array}{l}0,091 \\
(0,000)\end{array}$ & $\begin{array}{l}0,083 \\
(0,001)\end{array}$ & $\begin{array}{l}0,091 \\
(0,000)\end{array}$ & $\begin{array}{l}0,096 \\
(0,000)\end{array}$ \\
\hline TOT & & $\begin{array}{l}0,042 \\
(0,003)\end{array}$ & $\begin{array}{l}0,044 \\
(0,002)\end{array}$ & $\begin{array}{l}0,040 \\
(0,005)\end{array}$ & $\begin{array}{l}0,040 \\
(0,005)\end{array}$ & & & $\begin{array}{l}0,040 \\
(0,000)\end{array}$ & $\begin{array}{c}0,040 \\
(0,000)\end{array}$ & $\begin{array}{l}0,039 \\
(0,000)\end{array}$ & $\begin{array}{l}0,037 \\
(0,000)\end{array}$ \\
\hline $\ln ($ ARREARS) & & & $\begin{array}{l}0,233 \\
(0,088)\end{array}$ & & & & & & $\begin{array}{l}0,254 \\
(0,005)\end{array}$ & & \\
\hline STATED & & & & $\begin{array}{l}0,407 \\
(0,301)\end{array}$ & $\begin{array}{l}0,308 \\
(0,521)\end{array}$ & & & & & $\begin{array}{l}0,083 \\
(0,756)\end{array}$ & $\begin{array}{l}0,461 \\
(0,153)\end{array}$ \\
\hline $\ln$ (EMPLOY) & & & & & $\begin{array}{l}0,043 \\
(0,715)\end{array}$ & & & & & & $\begin{array}{c}-0,161 \\
(0,046)\end{array}$ \\
\hline $\mathrm{R}^{2}$ Adj. & 0,102 & 0,152 & 0,166 & 0,152 & 0,147 & 0,091 & 0,159 & 0,286 & 0,342 & 0,279 & 0,304 \\
\hline $\mathrm{N}$ & 137 & 137 & 134 & 137 & 137 & 92 & 92 & 92 & 92 & 92 & 92 \\
\hline
\end{tabular}

OLS - regressions; $\mathrm{p}$ - values in parentheses

Source: Data Sample of 165 Barter Deals in Ukraine in 1997

QUALITY $=$ firm's output per employee

BARTCOST $=$ index which takes the value of zero if the firm trades with only one other firm, and which tends to one if the firm trades with many firms

GROWTH = percentage deviation of firm`s output growth relative to the growth rate of GDP between 1994 and 1996

TOT $=$ SCASH - PCASH.

SCASH is the difference between the barter price and cash price in percent of the cash price for the trade credit side of the barter deal.

PCASH is the difference between the barter price and cash price in percent of the cash price for the goods payment side of the barter deal.

ARREARS $=$ firm arrears in percent of sales

STATED $=$ dummy variable with value 1 when the firm is state owned

EMPLOY $=$ firm's number of employees 
Table 6

Descriptive Statistics

\begin{tabular}{lccccc}
\hline Variable & Mean & $\begin{array}{c}\text { Standard } \\
\text { Deviation }\end{array}$ & Minimum & Maximum & $\begin{array}{c}\text { Number of } \\
\text { observations }\end{array}$ \\
\hline QUALITY & 19481,9 & 26109,9 & 1565,8 & 135133,3 & 152 \\
BARTCOST & 0,80 & 0,12 & 0,34 & 0,92 & 141 \\
GROWTH & 0,01 & 4,21 & $-2,03$ & 25,43 & 153 \\
TOT & 4,59 & 18,07 & $-168,00$ & 50,00 & 163 \\
ARREARS & 30,15 & 90,89 & 0,70 & 626,00 & 138 \\
EMPLOY & 4386,6 & 17518,1 & 8 & 130000 & 165 \\
BANK DEBT & 6,31 & 15,96 & 0 & 104,20 & 150 \\
STATED & & & & $\mathrm{D}=1$, & 43 observations \\
\hline
\end{tabular}

Source: Data Sample of 165 Barter Deals in Ukraine in 1997

\subsection{Cross Country Evidence}

In this section we examine the prediction of the model that a financial crisis may trigger a change that can substantially improve conditions for banking development. We will use country level data for 20 transition economies. Russia and Ukraine are among the transition countries with the most underdeveloped financial system. Our firm level evidence for Ukraine presented in the previous section suggests a separation between the real and financial sector in which bad quality firms only come to banks to raise liquidity. In this section we look for comparative evidence on the determination of bank intermediation at the macro level across transition countries. Our theory predicts that a country's level of bank intermediation is driven by the extent of information asymmetry between banks and firms, by the level of the government budget deficit, and by the level of barter trade. The governement's budget deficit induces banks to invest their excess liquidity in government securities which crowds out bank lending to the real sector of the 
economy. Barter trade leads banks to charge high interest rates so that they end up lending little to firms.

We start by examining commercial banks' lending rates. We expect that economies with a larger degree of information asymmetry between banks and firms, with a larger size of government deficit, and with a larger share of barter trade to have higher commercial banks' interest rates. We use commercial banks' 3 -months lending rates as the dependent variable. We measure the degree of information asymmetry between banks and firms by the country's EXPORT SHARE and/or by incoming foreign direct investment as a share of GDP FDI/GDP. Both variables are supposed to capture the average credit risk of the real sector. The idea is that the larger the export share and the larger the share of incoming foreign direct investment in percent of GDP the better the quality of the real sector and thus the lower the interest rates that banks will charge. In a market with credit rationing as we describe it here commercial banks lending rates are not driven by supply and demand but rather by the average credit risk of the pool of borrowing firms. Turning to the results in Table 7 this turns out to be the case, since both variables are negative and significant in the majority of specifications. The variables GOVDEBT and GOVDEF are both measures for the government's soft budget constraint. The former is the government's debt outstanding and the latter is the government's deficit both in percent of GDP. Lending rates will as well be affected by yields of government securities given the possibility for banks to invest in securities. ${ }^{20}$ As expected GOVDEBT or GOVDEF have both a positive and significant influence on interest rates except when the variable FDI/GDP (Stock) is included in the regression. The variable BARTER measures the share of barter in percent of sales in transition countries. As predicted the variable tends to increase banks' lending rates. Finally, we include the EBRD index of commercial law LEGAL to control for differences in the legal environment across transition countries. Not surprisingly, improvements in the effectiveness of the legal system tends to lower interest rates.

\footnotetext{
${ }^{20}$ In Russia the government offered exceptionally high yields on government bonds to make it attractive for banks to invest. In 1996 Russia was among the transition countries with the highest spread between bank loan and deposit rates. Our model suggests that bank loan rates are driven by the yields of government securities which may explain why the spread in Russia is particular wide. For the spreads in the banking sector in transition countries, see Transition Report 1998.
} 
Table 7

Determinants of Banks' Lending Rates

across 20 Transition Countries

Dependent Variable: commercial banks`3-months lending rates in percent per annum

\begin{tabular}{|c|c|c|c|c|c|c|c|c|c|c|c|}
\hline & \multicolumn{7}{|c|}{$\underline{1996}$} & \multicolumn{4}{|c|}{$\underline{1999}$} \\
\hline & (1) & (2) & (3) & (4) & (5) & (6) & (7) & (8) & (9) & (10) & (11) \\
\hline GOVDEF & $\begin{array}{c}15,529 \\
(0,009)\end{array}$ & & $\begin{array}{l}1,766 \\
(0,261)\end{array}$ & & & & & $\begin{array}{l}-0,250 \\
(0,870)\end{array}$ & & $\begin{array}{l}-0,682 \\
(0,720)\end{array}$ & \\
\hline GOVDEBT & & $\begin{array}{l}2,565 \\
(0,000)\end{array}$ & & $\begin{array}{l}-0,032 \\
(0,922)\end{array}$ & $\begin{array}{l}-0,012 \\
(0,971)\end{array}$ & $\begin{array}{l}-0,506 \\
(0,116)\end{array}$ & $\begin{array}{l}2,753 \\
(0,000)\end{array}$ & & $\begin{array}{l}0,039 \\
(0,697)\end{array}$ & & $\begin{array}{l}0,005 \\
(0,981)\end{array}$ \\
\hline FDI/GDP (STOCKS) & & & $\begin{array}{l}-1,210 \\
(0,222)\end{array}$ & $\begin{array}{l}-1,637 \\
(0,104)\end{array}$ & $\begin{array}{l}-1,531 \\
(0,135)\end{array}$ & $\begin{array}{l}-1,540 \\
(0,081)\end{array}$ & & & & $\begin{array}{l}-0,451 \\
(0,220)\end{array}$ & $\begin{array}{l}-0,595 \\
(0,362)\end{array}$ \\
\hline FDI/GDP (FLOWS) & & & & & & & $\begin{array}{l}-4,000 \\
(0,285)\end{array}$ & & & & \\
\hline EXPORT SHARE & & & & & $\begin{array}{c}-37,263 \\
(0,397)\end{array}$ & $\begin{array}{c}-110,724 \\
(0,023)\end{array}$ & & & & & $\begin{array}{l}17,014 \\
(0,767)\end{array}$ \\
\hline BARTER & & & & & & $\begin{array}{l}1,085 \\
(0,080)\end{array}$ & & & & & $\begin{array}{l}-0,049 \\
(0,948)\end{array}$ \\
\hline LEGAL & & & & & & & $\begin{array}{l}-37,686 \\
(0,036)\end{array}$ & & & & \\
\hline $\mathrm{R}^{2}$ Adj. & 0,273 & 0,630 & 0,208 & 0,096 & 0,077 & 0,556 & 0,695 & $-0,051$ & $-0,052$ & $-0,013$ & $-0,246$ \\
\hline $\mathrm{N}$ & 20 & 18 & 12 & 12 & 12 & 11 & 17 & 20 & 17 & 16 & 13 \\
\hline
\end{tabular}

OLS - regressions; $\mathrm{p}$ - values in parentheses

Source: International Monetary Fund, International Financial Statistics

BARTER = barter trade in percent of sales

GOVDEBT $=$ general government debt in percent of GDP

GOVDEF $=$ general government deficit in percent of GDP

EXPORT SHARE $=$ exports in percent of GDP

FDI/GDP $($ STOCKS) $=$ incoming foreign direct investment (stocks) in percent of GDP

$\mathrm{FDI} / \mathrm{GDP}$ (FLOWS) $=$ incoming foreign direct investment (flows) in percent of GDP

LEGAL = European Bank for Reconstruction and Development, index of commercial law; the index goes from 1 (never effective) to 5 (always effective) 
Next, we turn to analyse the level of bank intermediation across transition economies. Here we use as the dependent variable a country's level of bank credit to the private sector in percent of GDP. We want to test whether countries with a larger degree of information asymmetry between banks and firms, with a larger share of barter in their economy, and with a larger government budget deficit have a lower level of bank intermediation. Table 8 gives the results. As core variables we use the same variables as before in Table 7 explaining commercial banks' lending rates. We find that the variables EXPORT SHARE and FDI/GDP capturing the average credit risk of a country's real sector are both positive and significant at conventional levels suggesting that the lower the credit risk (the larger EXPORT SHARE and FDI/GDP), the more banks lend to the private sector. The variables GOVDEBT and GOVDEF as measures for the size of the government sector are both not significant (except for one specification) suggesting that the size of the government budget has no extra effect on the level of bank lending which works beyond the channel of banks' lending rates (in Table 7 we found that these variables tend to increase banks' lending rates). In specification 4 of Table 8 we include BARTER (and exclude GOVDEBT and GOVDEF because they tend to be correlated with BARTER ${ }^{21}$ ) and find as predicted that the larger a country's exposure to the non-cash economy the lower its level of bank lending to the private sector.

Furthermore, we include the EBRD index for non-banking financial institutions reform FINREG to control for differences in banking reform across transition countries. The index goes from 1 to 4 , the larger the number, the more reform has been undertaken in the country. We use the index for non-bank financial institutions as a proxy for bank reform rather than the index for banking reform itself to avoid problems of multicollinearity in the regression. Not surprising, the level of bank intermediation tends to increase in the countries with more progress in banking reform.

\footnotetext{
${ }^{21}$ Our model predicts that BARTER and GOVDEF will be correlated. The larger the budget deficit the larger the yields of government bonds and banks interest rates and thus the less attractive it is for firms to borrow from banks. They switch to barter instead. Furthermore, the more firms barter, the smaller will be the government's tax revenues, because firms will tend to exploit the possibility to evade taxes when bartering.
} 
We turn to the post financial crisis year of 1999 to see whether the financial crisis has changed the lending behavior of banks. This is done in columns (8) to (11) of Tables 7 and in columns (6) to (10) of Table 8. Four things are noteworthy from the tables. First, the two variables capturing the average credit risk of the producing sector EXPORT SHARE and FDI/GDP stop to have a significant influence on interest rates (Table 7) as well as on bank lending to the real sector (Table 8). Second, the effect of GOVDEF and GOVDEBT on lending rates becomes insignificant while GOVDEF has now in 1999 a marginally significant influence on bank lending to the privat sector. Apparently, the strong reduction in the fiscal budget deficit after the financial crisis has boosted bank lending to the private sector which has gone beyond its effect on lending rates. Third, barter stops to have a significant influence on interest rates as well as on bank lending.

To conclude, the drastic changes in the results of the regressions explaining interest rates and bank lending behaviour before and after the financial crisis do seem to suggest that the financial crisis has changed the behaviour of the banking sector in a fundamental way. The banking sector appears to connect with the real sector. This makes it possible for many transition countries, most notable for Russia and Ukraine, to abandon barter trade and to return to the cash economy. 
Table 8

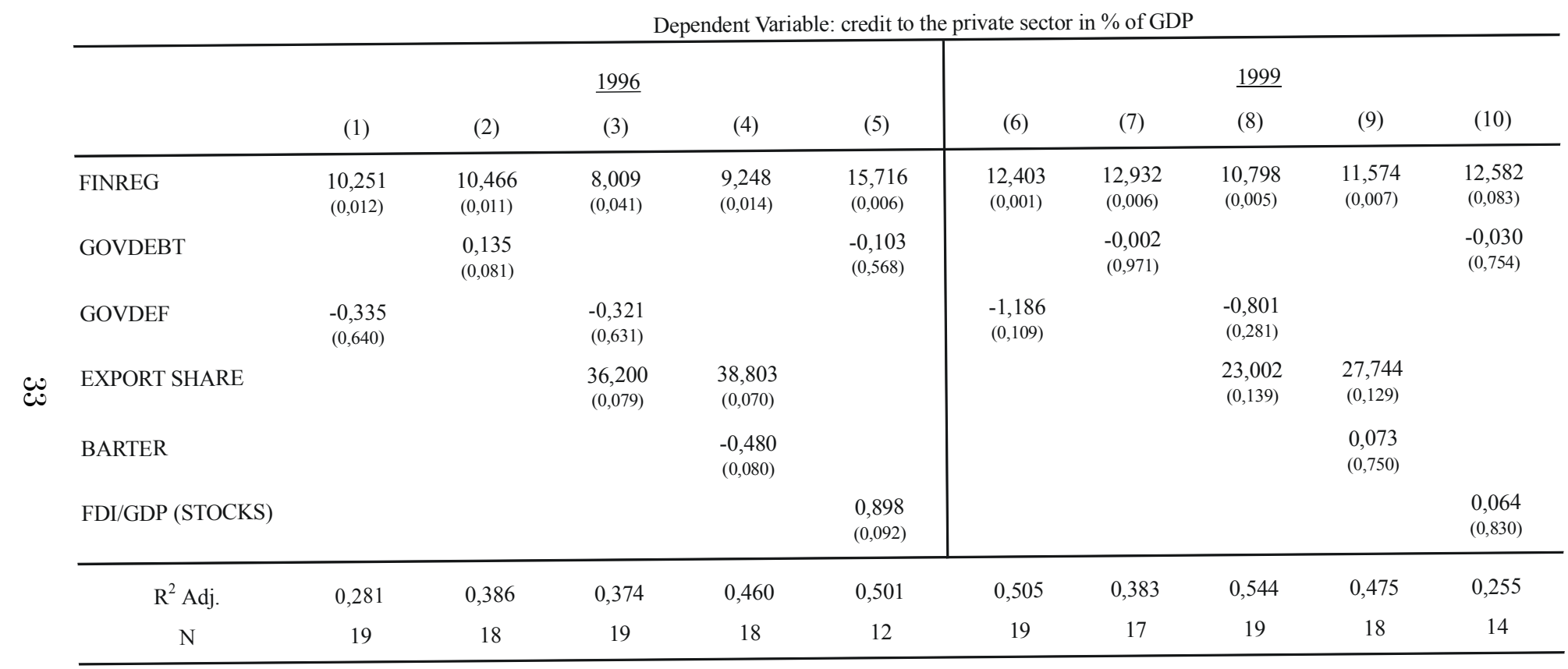

OLS - regressions; $\mathrm{p}$ - values in parentheses

Source: IMF, International Financial Statistics; European Bank for Reconstruction and Development (EBRD), Transition Report; World Business Environment Survey, World Bank EBRD, 1999

FINREG $=$ European Bank for Reconstruction and Development, index of non banking financial institutions reform index goes from 1 (little or no change from the previous regime) to $4+$ (industrialised market economy standard).

GOVDEBT $=$ general government debt in percent of GDP

GOVDEF $=$ government deficit in percent of GDP

EXPORT SHARE $=$ exports in percent of GDP

BARTER $=$ barter trade in percent of sales

FDI/GDP $($ STOCKS $)=$ incoming foreign direct investment (stocks) in percent of GDP

Determinants of Bank Credit to the Real Sector

across 20 Transition Countries in 1996 and 1999 


\section{Conclusions and Policy Implications}

This paper offers a model which explains why the financial sector is separated from the real sector in the economies of Russia and Ukraine. We argue that before the financial crisis of 1998 the economies of Russia and Ukraine were stuck in a banking development trap due to firms incentives to raise liquidity through barter trade. The large government deficit resulted in high yields of government bonds which induced banks to invest in treasury bills rather than to lend to firms. The financial crisis in 1998 reversed this process and acted as a trigger to get out of this trap. This has led to a strong economic recovery, to a decline of barter trade, and provided initial conditions for banking development. Whether economic recovery and growth can continue critically depends on whether the conditions for banking development can be sustained.

Our model has several policy implications of how the conditions for banking development can remain favourable. The highest priority has fiscal policy. It is critical that the government hardens its budget constraint and avoids to create an environment in which banks prefer to invest in government bonds rather than to lend to firms. The economic recovery has provided the conditions for this to happen, since in 1999 the government balance turned into a surplus in Russia as well as in Ukraine. Furthermore, our model suggest that in order to sustain banking development the banks' relative rate of return of lending to the firms in the real sector has to be kept high. Thus, in the first stage of bank development a moderate amount of competition in the banking sector is desirable. If bank competition is too strong, it will be difficult to maintain the incentives of banks to lend to the real sector and to invest in evaluating credit risk. If bank competition is too weak, then monopolistic banks will charge excessively high interest rates which will make firms turn back to barter trade.

Finally, our model suggests that a financial crisis, though viewed by many as a bad thing, can have its benefits as well. One of the benefits highlighted in this paper is that the crisis can lead an economy out of the banking development trap and to set the stage and initial conditions for financial development. This way the financial crisis has helped these economies to start to escape the non cash economy. 


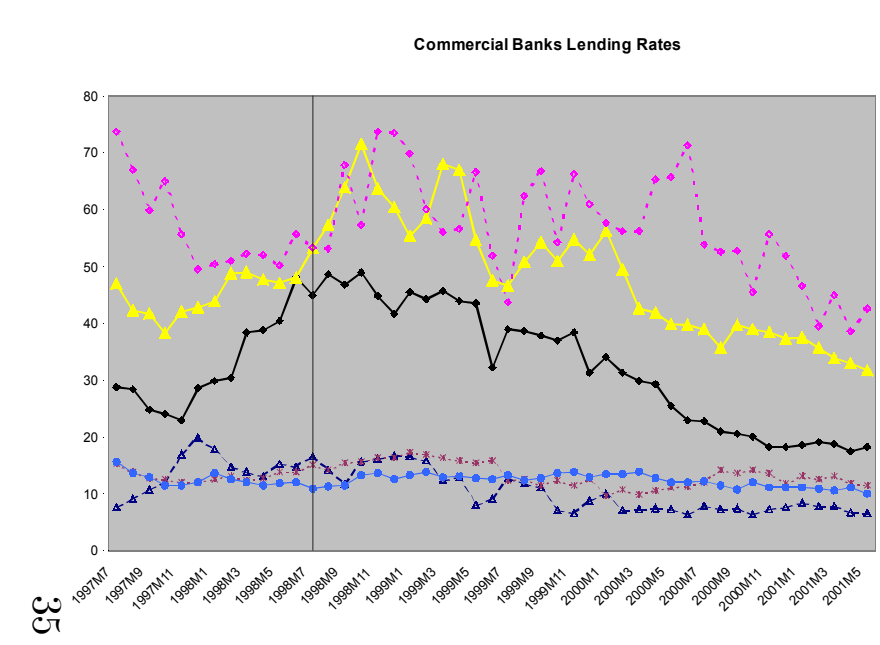

Figure 1

Treasury Bill Rates
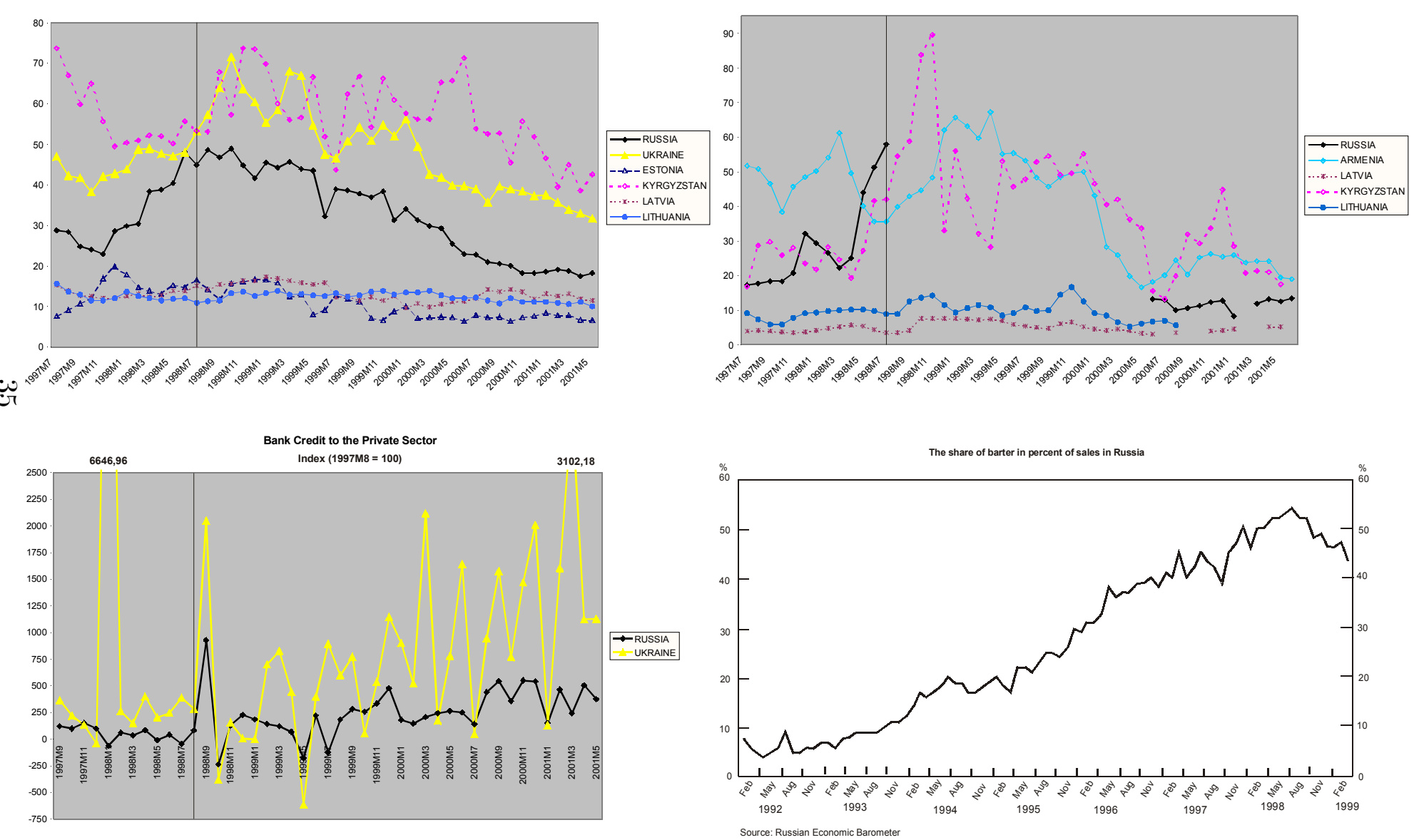


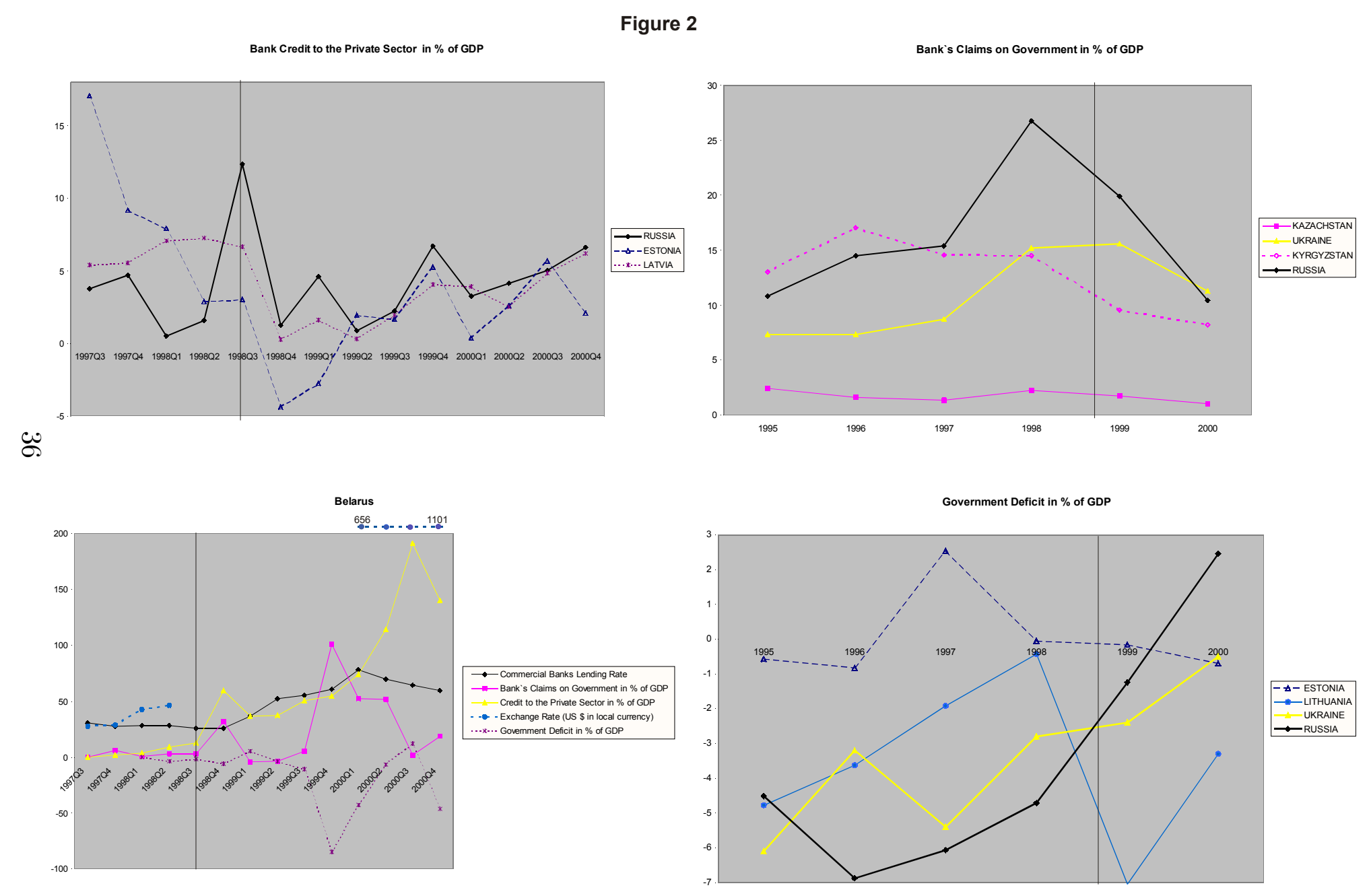




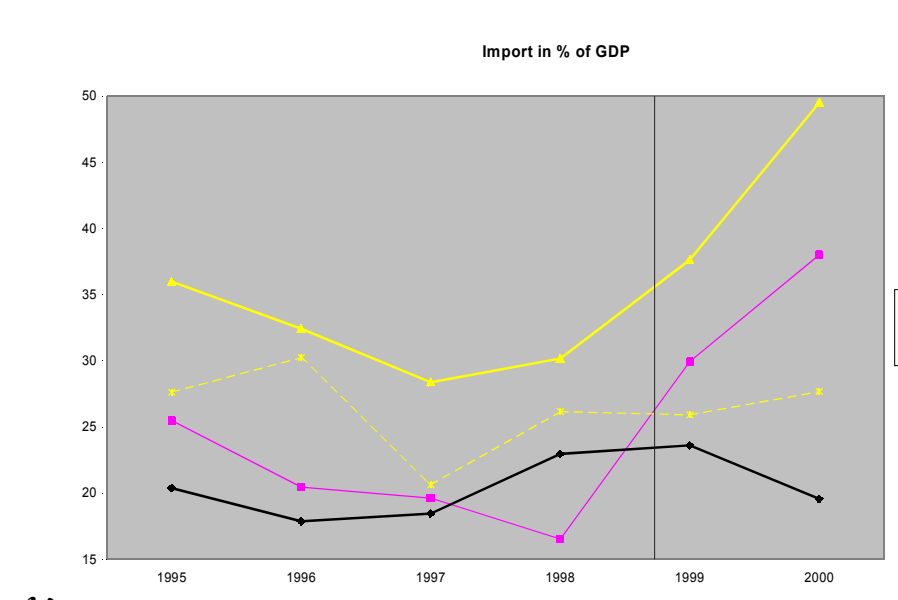

Figure 3

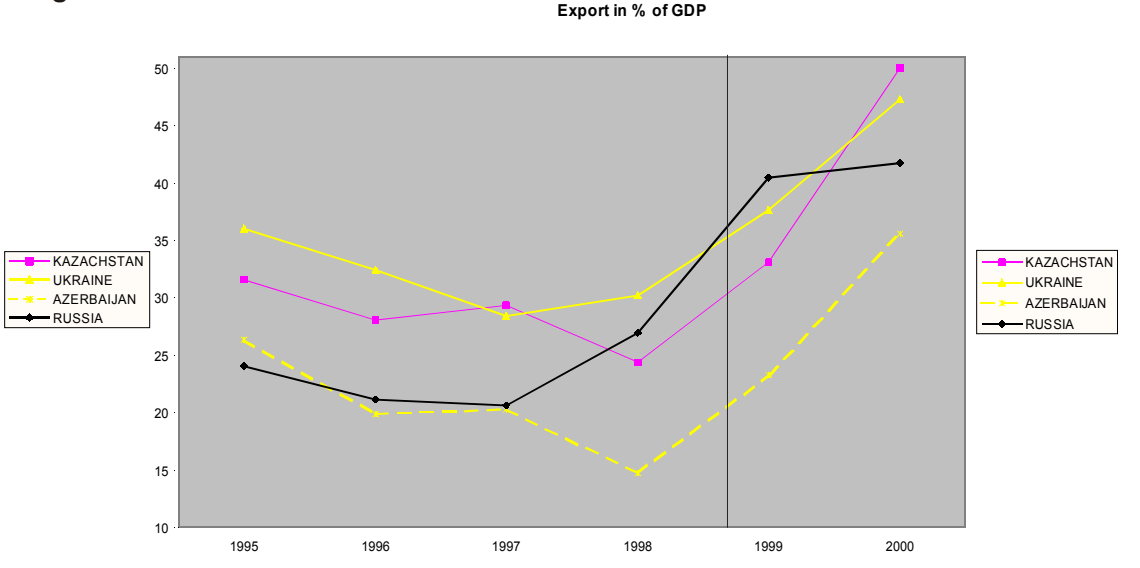

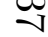

Exchange Rates (US \$ in local currency)
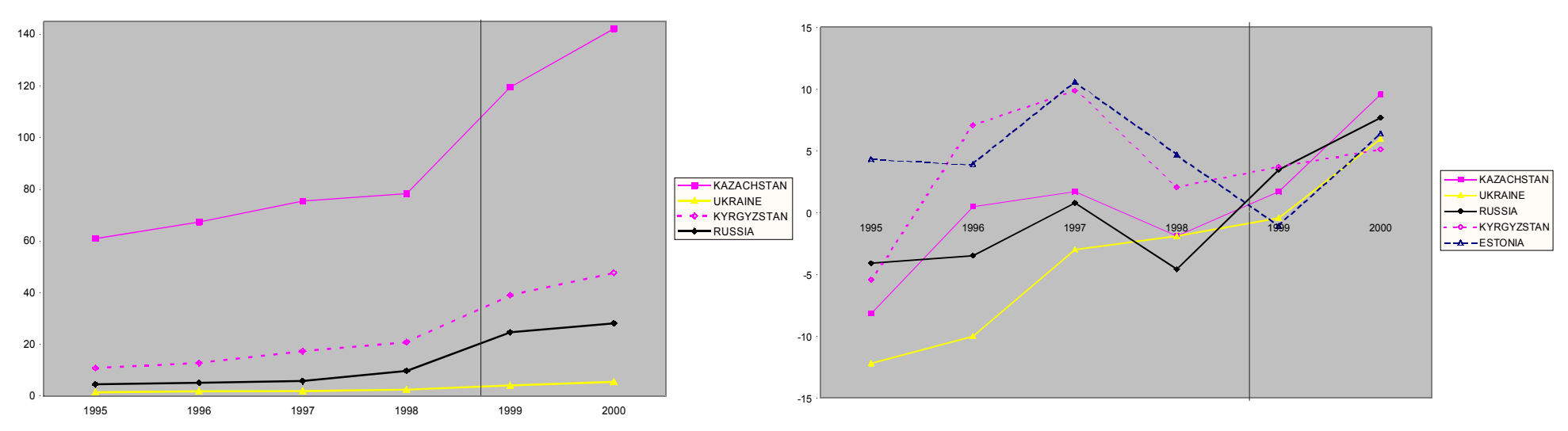


\section{References}

[1] Berglof, E. and P. Bolton (2002), The Great Divide and Beyond: Financial Architecture in Transition, Journal of Economic Perspectives, Vol. 16, No. 1, 77-100.

[2] Blanchard, O. and M. Kremer (1997), Disorganization, Quarterly Journal of Economics, 112, 1091-1126.

[3] Calvo, G. A. and F. Coricelli (1995), Output Collapse in Eastern Europe: The Role of Credit, in M.I. Bleyer, Calvo, G. Coricelli F. and A.Gelb (eds.): Eastern Europe in Transition: From Recession to Growth? World Bank Discussion Paper 196, World Bank, Washington 1995.

[4] Commander, S. and C. Mumssen (1999), Understanding Barter in Russia, European Bank for Reconstruction and Development, London.

[5] European Bank for Reconstruction and Development, Transition Report (1998), Transition Report, London.

[6] Gupta, P., D. Mishra, R. Sahay (2001), Ouput Responses to Currency Crisis, paper presented at the Annual Research Conference, International Monetary Fund, Washington 2001.

[7] International Monetary Fund (1999), Russian Federation: Recent Economic Developments, IMF Staff Country Report No. 99/100, Washington.

[8] Kaminsky, G.L. and C. M. Reinhart (1999), The Twin Crisis: The Causes of Banking and Balance of Payments Problems, American Economic Review, Vol. 89, No. 3, 473 - 500 .

[9] Loayza, N. and R. Ranciere (2001), Financial Development, Financial Fragility, and Growth, The World Bank and New York University, Mimeo.

[10] Loungani, P. and P. Mauro (2000), Capital Flight from Russia, IMF Policy Discussion Paper, Research Department, Washington.

[11] Marin, D. and M. Schnitzer (1999), Disorganization and Financial Collapse, Paper presented for the 5th Nobel Symposium in Transition Economics, Stockholm, Centre for Economic Policy Research CEPR, Discussion Paper No. 2245, London. 
[12] Marin, D. and M. Schnitzer (2002), Contracts in Trade and Transition: The Resurgence of Barter, Cambridge, MIT Press.

[13] Marin, D., D. Kaufmann, B. Gorochowskij (2000), Barter in Transition Economies: Competing Explanations Confront Ukrainian Data, in: P. Seabright (ed.) The Vanishing Rouble, Cambridge University Press.

[14] Organization for Economic Cooperation and Development OECD, Economic Surveys: Russian Federation 1997, Paris 1997-1998.

[15] Perotti, E. and St. Gelfer (2000), Red Barrons or Robber Barons? Governance and Financing in Russian Financial-Industrial Groups, European Economic Review, forthcoming.

[16] Shleifer, A. and D. Treisman (2000), Without a Map, Political Tactics and Economic Reform in Russia, MIT Press, Cambridge, Massachusetts.

[17] Westin, P. (2000), Export Revenues: Repatriation or Expropriation?, Russian Economic Trends, February, 3-10. 